\title{
The career adaptability among young adulthood : A systematic literature review
}

\author{
Syifa Nurul Ain Rasyidi* \\ Faculty of Education, University of Education Indonesia \\ email: cipenurul260@gmail.com \\ Sudaryat Nurdin Akhmad \\ Faculty of Education, University of Education Indonesia \\ email: snappbfipupi@gmail.com \\ Dadang Sudrajat \\ Faculty of Education, University of Education Indonesia \\ email: dadangsudrajat68@gmail.com \\ Nadia Aulia Nadhirah \\ Faculty of Education, University of Education Indonesia \\ email: nadiaulianadhirah@gmail.com
}

Received: March 17, 2021; Revised: April 10, 2021; Accepted: May 22, 2021

\begin{abstract}
The success of a person completing typical developmental tasks at certain stages of development lies in career adaptability. Career adaptability is an individual's readiness for a career in accordance with the effort to complete career-related developmental tasks. To suggest future development directions, this article systematically reviews the review literature on future adaptations. This article uses a systematic literature review (SLR) approach. This article uses 47 articles from 17 journals with research that has been conducted in various Asian countries, Europe, South America and other countries such as South Africa, China, Korea and Australia as the source. This article concludes that the adaptability possessed in adulthood is included in the high or mature category. Where it focuses more on aspects that are owned by the career and adult reasons why the adaptation at that time is high and the advantages that are owned when having the abilities possessed by a high or mature career. This article concludes with some suggestions for further research that could be produced in the future.
\end{abstract}

Keywords: career adaptability, adulthood, systematic literature review

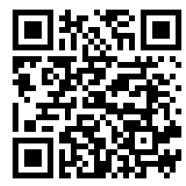

This is an open-access article under the CC-BY-SA license.

\section{Introduction}

In choosing and planning the right career, career maturity is needed, namely planning, exploration, knowledge of the world of work, and decision making (Savickas \& Porfeli, 2011). In order for individuals to be ready to choose a career, individuals need a good level of career maturity. 
Early adulthood career development theory has the readiness to make appropriate career choices. Individual readiness in making career choices is known as "Career Adaptability" (Savickas M., 2009).

Early adulthood is a period of transition from adolescence to adulthood. The transition period from adolescence to adulthood is commonly referred to as adulthood (Emerging Adulthood) which occurs at the age of 18-25 years. This period was marked by experimentation and exploration. At this point in their development, many individuals are still exploring the career path they want to take, what kind of individual they want to become, and what kind of lifestyle they want to be; living single, living together, or married (Santrock, 2011).

Career adaptability is the readiness of individuals in making careers by efforts to complete developmental tasks related to careers. Career maturity is an ongoing process. Career maturity requires more careful planning preparation than just getting something temporary. Savickas (2009) put forward the idea of career adaptability to refer to a set of four specific attitudes beliefs and competencies (attention, control, curiosity, and self-confidence), which form actual problem-solving strategies and coping behaviors that individuals use to synthesize their vocational self-concept with work roles.

According to Savickas (2013) if someone lacks career adaptability, then that person becomes apathetic, unable to decide, unrealistic, and refrained from achieving his career. Career adaptability has a relationship with the formation of vocational identity, where graduates who can adapt can have a variety of additional skills and make them more dynamic in the choice of occupations.

In this view, research aims to explore the adaptability of existing careers in adulthood. It is hoped that this literature review can contribute to career development in the context of adulthood. The contribution given is based on the study of knowledge and research results so that new knowledge can be obtained about the development of career adaptability. This study reviewed 47 articles published in 17 journals. The articles from the journal have been researched in various Asian, European and South American countries to other countries such as South Africa, China, Korea and Australia. With this study material, this paper is expected to be able to help academics and practitioners in studying and designing future programs in which individuals make their careers like and how in the future and the adaptability of this career will measure how ready and mature adults are in their careers.

\section{Method}

This article uses a literature review study method with a traditional review approach. Literature review is carried out to comprehensively determine the research that has been done previously to show a gap rationally to determine the solution and subsequent research (Denney \& Tewksbury, 2013). Data collection begins by identifying several studies on career adaptability, literature searches include peer-reviewed articles, published using databases and journals relevant in their fields such as Science Direct, Sage Journal, and Taylor \& Francis Online and to date the author has not found any articles. similarities in Indonesian journals using a systematic review of the literature. This database is included in indexed journals such as the journal of Career Assessment. South African Journal of Psychology, Journal of Career Development, Australian Journal of Career Development, Personality and Individual Defferences, Nurse Education Today, Journal of Vocational Behavior, Journal Pre-Proofs, Tourism Management Perspective, Journal of Psychology in Africa, The Anthopologist, The International Journal of Human Resource Management, AsiaPacific Journal of Teacher Education, Teacher and Teaching, Journal of Further and Higher Education, Interactive Learning Environments and Journal of Intellectual and Developmental Disability. Search all articles using "Career" and "Adaptability" which appear in titles, abstracts and keywords.

Interpretation is carried out by selecting journals that fit the criteria starting with reading abstracts, noting important points and relevance to research problems, recording bibliographies, making notes, quotations, or systematic compiled information (Nursalam, 2016). The researcher 
then carried out the analyst by making quotations and summaries that were arranged systematically in narrative descriptions to describe the findings of previous research.

\section{Findings and Discussion}

There are two processes of the maturity period that appear in early adulthood, first, the period from education to the world of work, and second, the period of change in the relationship or environment of family and friends towards the period of relationships between colleagues and partners (Dana Atzil-Slonim, 2015) . Findings from several studies so far show that career adaptability in adulthood has a positive contribution to adulthood attitudes and has a personal function with the psychological model of vocational development (Hartung, 2011) (Maree, 2017) (Savickas \& Porfeli, 2011).

Career adaptability has a dimension or aspect of career adaptability that contains four aspects, namely aspects of care, control, curiosity, and self-confidence (Savickas, 2009) (Johnston, 2016). All aspects of career adaptability address the problem of preparing adulthood for their career decision makers (Zi Chen, 2018). Starting from the caring aspect, namely the capacity to be aware and oriented towards career planning and to concentrate on motivation to prepare for future career assignments. Then the control aspect, namely the feeling of responsibility, persistence and assertiveness of the career that is determined in the future. Then there is the aspect of curiosity, namely the tendency to explore oneself and the environment to seek and find information that can help make future career decisions, both taking risks and curiosity for new knowledge and career competencies. The last aspect of self-confidence is the tendency to feel that you have the ability to master career-related challenges and be able to successfully overcome problems that may occur in the future (Celik \& Storme, 2017) (Coetzee \& Harry, 2015) (De Guzman \& Choi, 2013) (Johnston, Luciano, Maggiori, Ruch, \& Rossier, 2013) (Zacher, 2014).

In several studies it was found that the achievement of career adaptability possessed by adulthood was included in the category at a high level or could be considered mature. With several indications such as adulthood having a positive attitude in facing their work or having good readiness to face any existing career problems, both predictable and unpredictable (Johnston, 2016) (Coetzee, 2014) (Lily, 2017) ( Sinta, 2017) (Chong et al, 2015) (Savickas, 2012) (Savickas, 2009) (Andreas Hirschia, 2015).

Chong, et al (2015) argue that individuals with higher or mature career adaptability are more likely to have strategic career management for several reasons. First, individuals with high career adaptability tend to have better goal setting behaviors, and they also spend more time planning and experimenting with ways to achieve their goals. (Mark L. Savickas, 2012) Second, the ability to adapt in careers increases the tendency of individuals to proactively seek development opportunities (Savickas M., 2009), which contributes to skills and resources that individuals can use when managing their careers. Third, individuals with high career adaptation tend to take various job responsibilities positively (Andreas Hirschia, 2015).

Having this career adaptability helps to cope with current and anticipated tasks is one of the important factors for adulthood competitiveness in the labor market (Yu Haibo, 2017). Adulthood who is able to solve unexpected problems in the world of work can gain a competitive advantage over other job candidates. In this case, the form of competence and knowledge gathered through education and experience (Sherry E. Sullivana, 2006), is highly valued in the job market and leads to career success. Where career success is considered as a positive individual and work outcome resulting from career decisions, behavior, and individual work experience (Kraimer, 2001) (HESLIN, 2005) (THOMAS W. H. NG, 2005) (THOMAS W. H. NG, 2005).

Career adaptability in adulthood is higher or dominant in the ability of a strong control aspect. It can be seen from the way of self-motivation in strengthening the adaptability capacity of an individual's career in overcoming the challenges and threats faced by utilizing individual abilities 
for career development tasks (Coetzee \& Harry, 2015). This can be related to the current stage of adult life. Adulthood is a busy early life / career stage with job stability and career advancement opportunities (Savickas M., 2009). Savickas and Porfeli (2011) found a positive relationship between individual career adaptability and their vocational identity, deep career exploration behavior, and career commitment.

Seeking new or alternative job opportunities has become a necessity in today's unpredictable and dynamically changing career context. Hence career adaptability has become an important component of career development as it facilitates the adjustment of success and proactive career behavior (Savickas \& Porfeli, 2012; Tolentino et al., 2014). This study shows that individual career adaptability can be nurtured by strengthening their resilience. Raising individual awareness of how their resilience is related to their ability to manage their career development in the work environment can contribute to an increased sense of well-being and career satisfaction (Harry, 2014).

\section{Conclusion (and implications, recommen-dations, or suggestions, if any)}

Given the lack of research on career adaptability in adulthood, this study emphasizes that career adaptability in adulthood is more inclined to aspects of career adaptability such as aspects of care, control, curiosity and self-confidence. These findings inform about the reasons why adulthood has high adaptability and what benefits are gained from having high career adaptability in adulthood and the importance of having career adaptability in adulthood to strengthen their career adaptability and develop their career adaptability optimally. The suggested further research is to put more emphasis on further actions that need to be done to improve the adaptability of careers in adulthood including high and low categories.

\section{References}

Andreas Hirschia, A. H. (2015). Career adaptivity, adaptability, and adapting: A conceptual and empirical investigation. Journal of Vocational Behavior. http://dx.doi.org/10.1016/j.jvb.2014.11.008.

Annika F. Schuesslbauer, J. V. (2017). The Goal Paves the Way: Inspirational Motivation as a predictor of Career Adaptability. Journal of Career Development. DOI: $10.1177 / 0894845317718348$.

Celik, P., \& Storme, M. (2017). Trait Emotional IntelligencePredicts Academic SatisfactionThrough Career Adaptability. Journal of Career Assessment. DOI: 10.1177/1069072717723290.

Chen $\mathrm{Xu}, \mathrm{X}$. G. (2020). The role of career adaptability and resilience in mental health problems in Chinese adolescents. Journal Pre-Proofs. https://doi.org/10.1016/j.childyouth.2020.104893.

Chong, S., \& Leong, F. T. (2015). Antecedents of CareerAdaptability in StrategicCareer Management. Journal of Career Assessment. DOI: $10.1177 / 1069072715621522$.

Coetzee, m., \& harry, n. (2015). gender and hardiness as predictors of career adaptability: an exploratory study among black call center agents. South African Journal of psychology.

Cort W. Rudolpha, K. H. (2017). Career adaptability: A meta-analysis of relationships with measures of adaptivity, adapting responses, and adaptation results. Journal of Vocational Behavior. http://dx.doi.org/10.1016/j.jvb.2016.09.002.

Crites, J. (1976). A comprehensive model of career development in early adulthood.

journal of vocational behavior, 105-118.

Dana Atzil-Slonim, M. R. (2015). Changes in Romantic Competence and career Adaptability Among EmergingAdults in Psychotherapy. Study of Emerging Adulthood. DOI: $10.1177 / 2167696815620964$.

de Guzman, A. B., \& Choi, K. o. (2013). The relations of employability skills to career adaptability among technical school students. Journal of Vocational Behavior, DOI: 10.1016/j.jvb.2013.01.009. 
Denney, A. S., \& Tewksbury, R. (2013). How to write a literature review. Journal of criminal justice education, 24(2)

Eloisa Federici, C. B. (2019). The moderating role of HR practices on the career adaptability-job crafting relationship: a study among employee-manager dyads. The International Journal of HumanResource https://doi.org/10.1080/09585192.2018.1522656Management.

Fei Zhua, Z. C. (2019). Career construction in social exchange: a dual-path model linking career adaptability to turnover intention. Journal of Vocational Behavior. https://doi.org/10.1016/j.jvb.2019.04.003.

Ferreira, V. N. (2019). Students' psychological hardiness with career adaptability. Journal of Psychology in Africa. https://doi.org/10.1080/14330237.2019.1689468.

Hans G. K. Hummel, E. A. (2017). Game-based career learning support for youth: effects of playing the Youth@Work game on career adaptability. Interactive Learning Environments. DOI:10.1080/10494820.2017.1402062.

Hartung, P. J. (2011). Career construction: Principles and practice. In K. Maree (Ed.), Shaping the story: A guide in facilitating narrative career counseling (pp. 103- 120). Pretoria, South Africa: Van Schaik.

HESLIN, E. A. (2005). Conceptualizing and evaluating career success. journal of Organizational Behavior.

Hlad'o, P., Kvaskova, L., Macek, P., Je zek, S., \& Hirschi, A. (2019). Career Adaptability and SocialSupport of Vocational StudentsLeaving Upper Secondary School. Journal of Career Assessment. DOI: 10.1177/1069072719884299.

Homayoun Pasha Safavi, M. B. (2019). The association of psychological capital, career adaptability, and career competency among hotel frontal in employees. Tourism Management Perspectives. https://doi.org/10.1016/j.tmp.2019.02.001.

Johnston, C. S. (2016). A systematic review of the career adaptability literature and future outlook. journal of Career Assessment, 1-3.

Johnston, C. S., Luciano, E. C., Maggiori, C., Ruch, W., \& Rossier, J. (2013). Validation of the German version of the career adapt-Abilities scale and its relation to orientations to happiness and work stress. Journal of Vocational Behavior, DOI: 10.1016/j.jvb.2013.06.002.

Laramie R. Tolentino, P. (2014). Career adaptation: The relation of adaptability to goal orientation, proactive personality, and career optimism. Journal of Vocational Behavior. https://doi.org/10.1016/j.jvb.2013.11.004.

Maree, K. (2017). The Psychology of Career Adaptability, Career Resilience, and Employability: A Broad Overview. DOI 10.1007/978-3-319-66954-0_1.

Maria Cristina Ginevra, I. D. (2017). Career adaptability, resilience, and life satisfaction: A mediational analysis in a sample of parents of children with mild intellectual disability. Journal of Intellectual \& Developmental Disability. DOI: 10.3109/13668250.2017.1293236.

Mark L. Savickas, E. J. (2012). Career Adapt-Abilities Scale: Construction, reliability, and measurement equivalence across 13 countries. Journal of Vocational Behavior. https://doi.org/10.1016/j.jvb.2012.01.011.

Martin Stormea, P. C. (2020). A forgotten antecedent of career adaptability: A study on the predictive role of within-person variability in personality. Personality and Individual Differences. https://doi.org/10.1016/j.paid.2020.109936.

Melinde Coetzee, E. S. (2015). Employees' satisfaction with retention factors: Exploring the role of career adaptability. Journal of Vocational Behavior. http://dx.doi.org/10.1016/j.jvb.2015.

Michaël Parmentier, T. P. (2019). Examining the impact of emotional intelligence on career adaptability: A two-wave cross-lagged study. Personality and Individual Differences. https://doi.org/10.1016/j.paid.2019.05.052.

Nursalam. (2016). Metodologi Penelitian Ilmu Keperawatan: Pendekatan Praktis. Ed. 4. Jakarta: Salemba Medika 
Ozdemir, N. K. (2018). A qualitative exploration of the career adaptability of Turkish adolescents. Australian Journal of Career Development. DOI: 10.1177/1038416218821451.

Öznurİspira, E. E. (2019). The relationship of personality traits and entrepreneurship tendencies with career adaptability of nursing students. Nurse Education Today. https://doi.org/10.1016/j.nedt.2019.05.017.

Peter A. Creed, T. F. (2009). The relationship between career adaptability, person and situation variables, and career concerns in young adults. Journal of Vocational Behavior. DOI:10.1016/j.jvb.2008.12.004.

Peter McIlveen, H. N. (2018). Impact of teachers' career adaptability and family on professional learning. Asia-Pacific Journal of Teacher Education. https://doi.org/10.1080/1359866X.2018.1444141.

Rojewski, H. H. (2014). Gender-Specific Models of work-Bound KoreanAdolescents' Social Supports and Career Adaptability subsequent Job Satisfaction. Journal of Career Development. DOI: $10.1177 / 0894845314545786$.

Roque Neto, V. P. (2018). Career adaptability and entrepreneurial behavior in the K-12 classroom. Teachers and Teachingtheory and practice. https://doi.org/10.1080/13540602.2018.1526783.

Sara Santilli1, J. M. (2016). Career Adaptability, Hope, Optimism, and Life Satisfaction Italian and Swiss Adolescents. Journal of Career Development. DOI: 10.1177/0894845316633793.

Savickas, M. (2009). life designing: A paradigm for career construction in the 21 tst century. Journal of vocational behavior.

Savickas, M. L., \& Porfeli, E. (2011). Revision of the career maturity inventory: the adaptability form. Journal of career assessment, 355-374. DOI: 10.1177/1069072711409342.

Sherry E. Sullivana, M. B. (2006). The evolution of the boundaryless career concept: Examining physical and psychological mobility. Journal of Vocational Behavior. DOI: 10.1016/j.jvb.2005.09.001.

Sílvia Monteiro, J. A. (2018). Self-perceived competency and self-perceived employability in higher education: the mediating role of career adaptability. Journal of Furtherand Higher Education. https://doi.org/10.1080/0309877X.2018.1542669.

Sadika Ismail, N. F. (2016). Young emerging adults' graduateness and career adaptability: Exploring the moderating role of self-esteem. Journal of Psychology in Africa. http://dx.doi.org/10.1080/14330237.2016.1148417.

Santrock, J. W. (2003). A Life Span development edisi ketigabelas jilid II. Jakarta: Erlangga.

Thomas W. H. Ng, L. T. (2005). Predictors of Objective and Subjectivecareer Success: A MetaAnalysis. Personnel Psychology. https://doi.org/10.1111/j.1744-6570.2005.00515.x.

Turkan Argon, D. C. (2016). High School Students' Views on Lifelong Learning and Career Adaptabilities. The Anthropologist. https://doi.org/10.1080/09720073.2016.11892025.

Yu Haibo, G. X. (2017). Career Adaptability With or without Career Identity: HowCareer Adaptability Leads organizational Success individual Career Success? Journal of Career Assessment. DOI: 10.1177/1069072717727454.

Zacher, H. (2014). Career adaptability predicts subjective career success above and beyond personality traits and core self-evaluations. Journal of Vocational Behavior, DOI: 10.1016/j.jvb.2013.10.002.

Zi Chen, S. S. (2018). Chinese Youth Career Adaptability: Contextual Influences and Pathways to Positive Youth Development. Youth \& Society. DOI: 10.1177/0044118X18784058. 